\title{
インフォームド・コンセントの要件 \\ The legal principles of informed consent in Japan
}

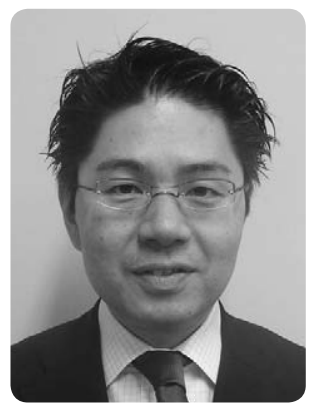

前田 正一

Shoichi Maeda

慶應義塾大学 大学院健康マネジメント研究科, 医学部医療政策・管理学教室（兼担）

Keio University, Graduate School of Health Management

医療従事者は，医療を行う際，あらかじめ患者からインフォームド・コンセントを得ていなければ ならない。その理由は，ひとつには，インフォームド・コンセントの手続きが，医療従事者・患者間 のコミュニケーションの確立に役立つことにあり，ひとつには，医療には重大なリスクが伴うことな どから，医的介入は，患者の自己決定を基本としなければならないとの考えが強まったことにある。

インフォームド・コンセントを行うためには，医療従事者は，事前に，インフォームド・コンセン トの要件を把握しておくことが重要である。例えば，説明要件との関係で，下記のような問いを作成 してみても (Box 内), 上記の重要性を容易に理解することができる。そこで，本講演では，イン フォームド・コンセントの要件を示すとともに，そのうち，特に説明要件に焦点をあて，関連裁判例 を紹介しつつ，その内容を検討する。

なお，本講演では，上記の点について，主として法的側面から解説を行うが，医療現場でのイン フォームド・コンセントの取り組みにおいては，医療従事者・患者間のコミュニケーションの点等, 本抄録の冒頭での記述内容にも配慮がなされることが重要である。

\section{《ご質問》}

(1)インフォームド・コンセントにおける説明では，どのような事項を説明すべきとされている のでしょうか。

(2)危険性についての説明では, どのような範囲の危険性について説明すべきとされているので しょうか。

(3)代替医療（予定している医療の代わりとなる医療）についての説明では，どのような範囲の 代替医療を説明すべきとされているのでしょうか。

(4)未確立医療は，説明すべき対象に含まれるのでしょうか。

(5)「熟慮の機会の確保」とは何でしょうか。

(6)患者に合併症が生じ，医療行為に過失がない場合でも，医療側は損害賠償金を支払わなけれ ばならない場合があるのでしょうか。あれば，それはどのような場合でしょうか。

(7)合併症の治療のための医療費は，患者が支払うのでしょうか，医療機関が支払うのでしょう か。それは，何によって決まるのでしょうか。

8)説明・同意文書には，どのような内容を，どのように示すとよいのでしょうか。 


\section{略 歴}

1972 年 福岡県生まれ

九州大学大学院医学系研究科博士課程修了 (博士 (医学))

九州大学大学院医学研究院 助手

東京大学大学院医学系研究科 生命・医療倫理人材養成ユニット 特任講師

東京大学大学院医学系研究科 医療安全管理学講座 特任助教授・准教授

(現在)

慶應義塾大学 准教授

(大学院健康マネジメント研究科, 医学部医療政策・管理学教室（兼担)）

（主な役職（2012.2））

文部科学省 科学技術・学術審議会 専門委員のほか,

東京大学医学部, 東京大学医学部附属病院, 医療系共用試験実施評価機構, 日本医療機能 評価機構，医学系学会，医療機関等で，医療事故・医療倫理等に関する委員会委員

(主な著書)

ソーリー・ワークス（医学書院，2011）

病院倫理委員会と倫理コンサルテーション（勁草書房, 2009）

医療事故初期対応一その理論と実践（医学書院，2008）

医事法学概論（日本医師会, 2008)

医療・介護と個人情報保護法（金芳堂, 2006)

インフォームド・コンセント一その理論と書式実例（医学書院，2005）

など 